Tarih Kültür ve Sanat Araştırmaları Dergisi

Revue des Recherches en Histoire Culture et Art مجلة البحوث التاريخية و الثقافية و الفنية
Vol. 7, No. 5, December 2018

Copyright (C) Karabuk University

http://kutaksam.karabuk.edu.tr

\title{
DOI: 10.7596/taksad.v7i5.1409
}

Citation: Parveen, S., \& Zahoor, M. (2018). Derailed Democracy and Daily Dawn: A Critical Analysis of Editorials and Columns (October 1999 - August 2002). Journal of History Culture and Art Research, 7(5), 314-324. doi:http://dx.doi.org/10.7596/taksad.v7i5.1409

\section{Derailed Democracy and Daily Dawn: A Critical Analysis of Editorials and Columns (October 1999 - August 2002)}

Saima Parveen ${ }^{1}$, Muhammad Abrar Zahoor ${ }^{2}$

\begin{abstract}
Pakistan inherited administrative institutions from its predecessor colonial state. These institutions were highly centralized, developed over a time period of many centuries and bequeathed intact. Contrastingly, the political and representative institutions and traditions that Pakistan inherited were moribund because they could not experience smooth sailing and hence not evolved over a reasonable time span. Unfortunately political parties could not develop democratic culture which paved the way for civil and military bureaucracy to overcome established institutional structure. By holding very strong power, the institutions of civil and military bureaucracy continued to override what they found in the form of representative. The tide could not be turned and Pakistan went through more than three decades of dictatorships. Media also faced the same fate and could not play the role of healthy criticizer for government as was due on it being the fourth pillar of state. The media can play its constructive role in democracy only if there is encouraging environment that allow them to do so. Democracy and media both suffered not being in good and strong hands during this period. This research paper is an effort to explore, evaluate and analyze the role of Dawn newspaper in responding to the fourth military coup of Oct 12, 1999. The media outlet studied under this research paper is an English daily newspaper "Dawn". It is an analysis of the role of Dawn in public opinion making, developing political consciousness among Pakistani masses and playing the role of healthy and balanced opposition for military coup of Oct 12, 1999. The findings reveal that despite the friendly behavior of Musharraf government towards media, the response of Dawn to fourth martial law of country's history was very careful and reserve unlike other newspapers of Pakistan. Dawn not only remained stick to its policy of neutrality but also analyzed the events very critically. This research paper is a qualitative analysis of the response of Pakistan's relatively reliable and unbiased newspaper Dawn towards the fourth military coup and political developments mainly, Provisional Constitutional Order (PCO), judicial validation of the military coup and Legal Framework Order (LFO).
\end{abstract}

Keywords: Dawn, Democracy, Legal framework order, Martial law, Media, PCO, Supreme court.

\footnotetext{
1 Lecturer, Department of History and Pakistan Studies, University of Sargodha, Sargodha E-mail: nazarsaima69@gmail.com

${ }^{2}$ Assistant Professor, Department of History and Pakistan Studies, University of Sargodha, Sargodha E-mail: abrar.zahoor@uos.edu.pk
} 


\section{Introduction}

The Washington Post, an influential newspaper of United States, carries a statement beneath its logo that "democracy dies in the darkness" which speaks volumes about the necessity of vibrant and free media for the growth of democracy. It is said that democracy paves the way towards free and liberal media and gives it the courage and space to play its due role, but in the case of Pakistan, media paved the way for democracy. According to a perceptive analysis, free media emerges out of democracy but the case of Pakistan is different, here democracy is emerging out of free media (Hiel, 2008). In fact both of them are connected with each other and have to keep an eye on one another.

The media have to evaluate government actions and performance to construct the public opinion. Similarly, a democratic government not only has to give media its due rights but also to have a check on them whether they are performing their duties honestly or are just trying to catch public attention by fair or unfair means. As M. Zia-ud-din, the former SAFMA-Pakistan president, said aptly in his introductory remarks in SAFMA National Conference-4, that there is no such thing as government friendly media. There will always be a tussle between media and government. We are the watchdogs. The question is who is doing to watch the watchdogs. It is one of the duties of government to watch these watchdogs through a regulatory body which is autonomous but works under the government.

Print media is the oldest media of Pakistan and it existed before independence. It was, and still is, the highly influential public opinion maker because every newspaper reader has great confidence in the newspaper of his choice. In Pakistan, during the past decade print media has undergone significant changes. The total number of daily, weekly and monthly publications in 1997 was 4,455 but six years later in 2003, the number was reduced to 945 (Media in conflict, 2009). Perhaps this change is due to increasing number of private channels in electronic media, but it does not mean that print media has lost its influence. It is still the highly influential public opinion maker, and although the number of newspapers has decreased, the circulation has increased. In 2003, for example, the daily distribution of newspapers was 6.2 million (Media in conflict, 2009). A private market research company, MEMRB, estimates that, in 2007, approximately 14.6 million Pakistanis read a newspaper at least once a week (Eye on Pakistan, 2009). With the improvement in literacy rate the readership of newspapers has also increased. Pakistani public regards printed word as authoritative which reinforces public opinion making the role of print media important as against the other forms of media in Pakistan. The present study has taken editorial page of Dawn as basic unit of analysis because Dawn was never a passive newspaper and it always upheld moderate and fair opinion and has been a quality newspaper. The revolutionary change of media policy during Musharraf era also influenced Dawn and it become more blunt, more influential and fair in its opinion. The way Dawn dealt with the fourth military coup and the proceeding events after that like PCO, Judicial validation of Martial Law, Judicial trial against Mian Nawaz Sharif and LFO is the main focus of the research. It will be analyzed through this study that unlike other newspapers in Pakistan how differently, pragmatically and neutrally Dawn reviewed the above mentioned issues.

\section{Newspapers Groups}

There are three major groups of newspapers in Pakistan: a) The Jang Group of Publications; b) The Dawn Group of Publications; c) The Nawa-i-Waqt Group of Publications. Jang, the largest group of Newspapers in Pakistan, was established by Mir Khalil-ur-Rehman in 1942 in Delhi (Mezzera and Sial, 2010). Jang group comprises four TV channels and publishes the Urdu language daily Jang, The News International, Mag weekly and Awam. The News is the second largest English Newspaper of Pakistan, and as compared to Jang, it is comparatively critical about political affairs. Another major group of publications of Pakistan, Nawa-iWaqt was established by Hameed Nizami in 1940 (Mezzera and Sial, 2010). Daily Nawa-i-Waqt is the largest 
Urdu daily. Its major publications are, daily Nawa-i-Waqt, The Nation (English), weekly Magazine Family, and a Sunday Magazine Nida-i-Millat.

\section{The Dawn Group of Publications}

As it runs on the face of this newspaper, this group was founded by Muhammad Ali Jinnah in 1941, but Dawn was first published in 1947 (Mezzera and Sial, 2010). It is the second largest media group of Pakistan, with all English language publications. The main publications of Dawn group are The Star, Herald and Dawn. Dawn is the largest English Newspaper of Pakistan. It has over 138,000 circulations, a day, and a total readership base in excess of 759,000 (Dawn, 2017). The reason behind such a huge readership is that Dawn has a moderate and tolerant approach towards events and issues.

\section{Why Dawn?}

The first Martial Law was imposed in Pakistan by Gen. Ayub Khan in 1958, while the second was imposed by Gen. Yahya Khan in 1969 and the third one was imposed by Gen. Zia in 1977, but the reaction of media whether it was electronic or print against these martial laws was not effective. Media was not strong enough to influence public opinion, so that the military governments were not obliged to bother about media. Military governments were free to do whatever they wanted. That is why Ayub's despotic rule lasted for 11 years. Gen. Yahya khan, the second martial law administrator, was so busy in his merry making and luxurious life that he did not bother to solve the political issues between Awami League and Peoples Party. Political power could not be transferred after elections of 1970 and then crises deepened. The third army ruler Gen. Zia ruled with iron hand till 1988 (for almost 10 years) and was in the mood of ruling for some more years when he died in an air crash.

Role of right-wing print media against the authoritarian practices of Zulfikar A. Bhutto and the left-wing print media against Zia ul-Haq was effective to a certain degree but not at all decisive. But the case of fourth martial law was different because from 1999 onwards the media became gradually influential on publicopinion making process. The media became a threat to the governments and provided an important check on despotic actions.

\section{Dawn and the Imposition of Martial Law by Gen. Musharraf}

On 12 October 1999 Prime Minister Nawaz Sharif dismissed chief of army staff Gen. Pervez Musharraf. Then the head of Inter-Services Intelligence (ISI) Lt. General Zia-ud-din was promoted to the rank of General and then appointed as new chief of army staff but army refused to obey these orders of the Prime Minister (PM) and took over the control of country. The legitimate government of Nawaz Sharif was dismissed and Gen. Pervez Musharraf became chief executive of Pakistan. When on the eve of Tuesday, 12 October 1999, army took over the control of the country, the situation was very confusing. No one was clear about what was going on. So, newspapers could not capture the issue properly but on Wednesday 13 October 1999 Gen. Musharraf addressed the nation on TV and announced that army had moved in. Editorial of Dawn on 14 Oct 1999 commented on the issue that the situation is very confusing and Mr. Nawaz is the most responsible person for this. He used all the fair or unfair means to fulfill his lust for power. Although it is the right of an elected government to be allowed to complete its tenure yet in the case of Mr. Nawaz it's difficult to prove (At the crossroads, 1999). In fact, on the imposition of Martial Law on 12 October 1999, no newspaper criticized the step taken by army because, although Mr. Nawaz was an elected PM, his behavior with other institutions was more despotic than any military ruler. 
Nawaz Sharif used the slogan of "heavy mandate" to fulfill his lust for power, as M.H. Askari wrote in his column that Nawaz Sharif's biggest weapon of the so-called heavy mandate which he often used to meddle with the constitution was really a myth. Facts revealed by experts confirm that the voter turnout in the 1997 election was the lowest ever in a national elections in Pakistan. Only 35 percent of registered voters came on the polling day to vote (Askari, 1999). The column further elaborated that the lust for power of Sharif's was so intense and insatiable that it wasn't fulfilled even with his so-called heavy mandate. It was also a suspicious factor of how he got his "heavy mandate" with lowest turnout of national elections in history.

A column of 15 Oct. 1999 written by Ayaz Amir also commented on the same thing and considered the military coup the need of time or situation created by Nawaz Sharif and stated that the army hand was forced to move in otherwise the Sharifs wanted to do to the army what they had done to the Supreme Court: to sow the seeds of dissention in its high officials so as to make it ineffective as a check on their ambitions (Amir, 1999). Army was appreciated for taking such a step of dismissing a democratic government of Mian Nawaz Sharif because of its despotic actions against judiciary and army. Mr. Irfan Hussain stated the same fact in his column of 16 Oct 1999 and analyzed that in early 12 years of elected civilian governments no one could manage to prove that democracy is better than dictatorship. So, nobody is worried for the sacked Nawaz Sharif government (Hussain, 1999). And it was not only in the case of Nawaz government; whenever the political government is dismissed by any military ruler in Pakistan no one shed tears on the dismissal, politicians have never proved themselves better substitutes of military rulers. That is why nobody laments the dismissal of politicians like Nawaz Sharif.

There was a sense of relief in the air from Nawaz government, perhaps people were fed up with such type of democracy and politicians. Ardeshir Cowasjee stated in his column that the international community who sits thousand miles away from our country calls for restoration of democracy is blind to the fact that democracy was never there to be restored. The people who demand that the country must be ruled according to the constitution but the question is, according to which constitution? The constitution of 1973 or the one we have at present amended and re-amended (Cowasjee, 1999). The people were despaired of democratic governments of Nawaz Sharif and Benazir Bhutto but it was a very clear feeling that if army rule prolonged, it will be another mess to be cleaned up. So, the question about army's future planning was aroused in the editorial of 14 October 1999, and the brief statement given by COAS is silent about the nature of the army's role or how long the present interval will last (Cowasjee, 1999).

The address of Gen. Pervez Musharraf was not clear about the future plan that for how long the army rule will last and what will be the role of army in future politics: that is, whether it will go back to barracks or will stay in politics. Military rule was welcomed because it had replaced the unpopular Nawaz government, but there was also a demand for new elections because the long stay of army in politics and government was likely to cause problems. As editorial of 16 Oct 1999 in Dawn stated that a long period of military rule only complicates the problem whose solution is cited as the reason for its imposition (Democratic rule is of the essence, 1999). Army is welcomed to clean up the mess, recover the bank loans and unpaid taxes and to assure the independence of Election Commission to hold fair and free elections and to hand over the politics to an elected democratic government. It further stated that the people want good governance what they have not got from the so-called elected governments. People want improvement in their lots (Amin, 1999). It has become like a cycle of martial laws, whenever martial law is imposed, it is taken as a solution to all the problems of common masses but these hopes have never came true in our national political history.

Pakistani masses always welcomed the military dictators in the hope of change in their lots and life styles but these hopes never came true. Same was the situation with the Martial Law of 1999, as Ayaz Amir's column narrates that how it could be expected that General Musharraf is going to be successful where his 
great predecessors-Ayub, Yahya and Zia so miserably failed? In the beginning army has always been looked upon as the solution, very soon it seems as part of the problem (Amir, 1999). On the other hand army prolongs its stay and considers it indispensible to safeguard "national interest." Threatened from this fact, Dawn's editorial and columns again and again questioned about army's future intentions, because the long stay of army in politics not only distorts the political institutions but it also affects its own professionalism. The editorial of 17 October 1999 stated the same reality that it is in collective interest of the army and the nation that military interval should not be a day longer than necessary and it was also strongly recommended that democracy should be restored in months rather than years (In months not years, 1999).

There was an open demand of declaring a date for elections in editorial of 19 Oct. 1999 and it is quite logical that if a deadline is fixed for all essential tasks, it will be a great help in organizing to achieve the intended results on schedule (Question of Time-frame, 1999). But it is also a bitter fact that military has never winded up its work within time but has always prolonged its tenure. So, although like other media outlets of Pakistan, Dawn also took a sigh of relief on getting rid of Nawaz Sharif yet was concerned with the restoration of democratic values. It was a contradictory situation, however. As the column of Ayaz Amir narrates, the army coup's whole case for dismissing Nawaz moves round one point that by trying to remove Gen. Pervez Musharraf from the post of army chief and replacing him with Lt. General Zia-ud-din was an attempt to seed factionalism in the army. But what logic could be given in suspending constitution and banishing democracy? (Amir, 1999) In fact, after the coup, military had once again started to consider itself indispensible in politics for Pakistan as it had done many times previously.

Incapability of Nawaz government paved way for another military dictatorship in Pakistan. The previous experiences of military rules were not so pleasant that the coup of 1999 should be welcomed but like previous military coups it was also considered a revolution and not only common people but media was also hoping of some miracles as were expected from previous military dictators. Not only Dawn but also the whole media were expecting the end of the crisis and were nourishing the hope that everything was going to be set right. But very soon all hopes ended as the intentions of Gen. Musharraf became clear which were not different from his predecessors.

\section{Dawn and Supreme Court's Validation of Military Coup of 12 Oct 1999}

On 12 Oct 1999, Gen. Musharraf suspended the 1973 constitution, along with the national and provincial assemblies. Due to the popularity or may be the fear of Pakistan's armed forces among masses this change was welcomed by the people of Pakistan as well as media outlets. It is the part of Pakistan's history that military coup has always been welcomed here, but it is also a fact that people very soon become tired of the military rulers and start struggle to get rid of them. As Ayaz Amir says that it is true that whenever military takes control forcibly, the general public lets its hopes take flight as a result of which expectations sour. This happened not only in the case of Gen. Musharraf but his predecessors also. But with the passage of time reality reasserts that the melodic sounds being heard are not different from the sounds heard before (Amir, 2000).

People's appetite for the so-called "Sham Democracy" comes back and they again start chasing the political parties and taking out processions with same enthusiasm. Same promises are made with the people; the same drama is played again and again. Same was the issue of validation of military coup from Supreme Court. The military takeover was challenged by Nawaz Sharif's colleagues under the article 184(3) of the constitution (Behuria, 2000). The Supreme Court set the date of hearing on January 31, 2000 and Gen. Musharraf had still not touched the judiciary and was uncertain about the verdict which was going to be given by Supreme Court. So, he decided to administer the fresh oath of office to all judges of the Supreme 
Court on Jan 26, 2000. Eighty nine judges out of one hundred and three took oath under PCO (Provisional Constitutional Order) (Behuria, 2000). The remaining fourteen refused to take oath under the PCO.

Then on the whole political situation was clear for the General Musharraf. It was evident that the government's claims of supporting judicial independence sounded void in the aftermath of the promulgation of the PCO (Sattar, 2000). Now Gen. Musharraf was certain about the verdict of the Supreme Court that it would be in his favor on the issue of military coup of 12 Oct 1999. It was the same act performed by former martial law administrator Gen. Zia-ul-Haq. According to Ayaz Amir, it was in March $1981 \mathrm{Gen}$. Zia-ul-Haq performed the same act whose affirmations to hold elections in 90 days were more vocal than Gen. Musharraf. Excluding a few honorable exceptions, most of their lordships, preferred judgment to bravery by swearing loyalty to Gen. Zia's PCO. Again shunning rashness and opting for practicality, the overwhelming majority of their lordships, have sworn loyalty to another PCO (Amir, 2000).

Taking oath from judges under PCO resulted as it was wished by Gen. Musharraf and on May 12, 2000 Supreme Court announced that Gen. Musharraf, Chairman of Joint Chief of Staff Committee (CJSC) and Chief of Army Staff (COAS), had validly captured power by using an extra constitutional step, in the national interest and for the welfare of the people (Behuria, 2000). The verdict was well in line with Justice Munir's "doctrine of necessity" which he had given in the favor of Gen. Ayub's takeover in 1958. Supreme Court also referred to the misrule of Mian Nawaz Sharif who had created the condition for radical transformation. The court, however, asked the Chief Executive to hold the elections within three years of takeover before 12 Oct, 2002.

The comments of Dawn in its editorial about the verdict were very positive and pragmatic. It stated that previous examples in this regard are not encouraging. In Nusrat Bhutto case in 1977 Supreme Court gave the period of six to eight months to Gen. Zia for holding elections and after this assurance Gen. Zia was given the judicial sanction to amend the constitution, nobody needs to be reminded that what became of that six-to-eight months pledge. But still the verdict given by Supreme Court on May 12, 2000 is the only time table on offer and in the absence of anything better a reference point whereby the conduct and progress of the Musharraf regime will be judged both at home and abroad (What the verdict means, 2000). Musharraf government has never announced a date for elections, and this threat was not baseless because this military regime was also going to be as long as the previous ones.

So, the verdict given by Supreme Court was welcomed because it gave a time table or deadline for holding of elections. But it is also a historical fact that such verdicts or deadlines for elections given by Supreme Court have never been followed in our country. On the other hand, military takeover was given a judicial validation under the so-called "doctrine of necessity"; chief executive Gen. Musharraf was allowed to make amendments in the constitution. The verdict was taken as triumph of military dictatorship. Therefore, the editorial of Dawn reminded the government that the government should remind that the time given to it by Supreme Court validating the military takeover of 12 Oct is not open-ended. The basic task is to hasten towards the process of accountability and reform and going back to barracks after handing over the power to an elected government (An example to follow elsewhere, 2000).

Although the previous examples were not so encouraging yet media was still hopeful about elections. It stated that the landmark verdict which requires that elections be held to national and provincial assemblies within three years virtually provides a roadmap for the restoration of democracy (Bhatty, 2000). The only reason for taking positively the verdict about validation of military takeover of 12 Oct was the time table for elections announced in the verdict. A column by Humayun Khan took the verdict as an encouraging step towards restoration of democracy. He commented about the verdict that the judgment of May 12 strengthens the case of restoring democracy with joining hands with military and politicians. It opens the way for co-operation over a wide range of objectives that are there for all to see (Khan, 2000). 
Nothing was different from previous military regimes but people and media were still hopeful about the future. They were still hoping for changed military motives. It was still an opinion that military will not try to prolong its tenure but would hand over the government to elected political leaders. But the facts remained the same. If holding free elections and handing over power to the elected government was the goal, was the Nawaz government not elected? Ayaz Amir very ironically compared Gen. Musharraf with Gen. Ayub in a column: 'I promise you whenever it comes to select between the constitution and the country, I will choose the country.' Gen. Ayub Khan-1958, 'Constitution is worthless if God forbid Pakistan does not survive.' Gen. Pervez Musharraf-2000. These words reveal the bleak outlook of these self styled saviors of the country as if constitutionalism left unchecked and is not tempered by the kind militarism, posed a threat to national integrity. This theory of politics reveals primitive state of mind (Amir, 2000).

The comparison gives a clear picture that all the military dictators, with no exception, exhibited same state of mind. They are never able to determine that their major role is to defend the country not to do the politics. In Pakistan, politicians have always created the situation to invite military coups. Military rulers come to solve the problems but later on became part of the problems, for which they were considered solution. They have always promised to restore democracy as soon as possible for them but have always tried to remain stuck to the chair. Few analysts believe and they assert that the situation will remain the same till the role of military in democratic dispensation is not clearly defined. However they need to understand that such role will again be extra-constitutional because the constitution has already outlined the role and responsibility for army as an institution.

\section{Dawn and Mian Nawaz Sharif's Trial}

It has become a tradition of Pakistan's political history that the one who took over as a ruler tries to eliminate his predecessor from the political scene. In fact, it is the absence of democratic traditions that our rulers feel threat from their opponents and try to destroy their political careers. On 12 Oct. 1999, when army took over the power, the main reason behind, as it was stated then by army, it was the government's plan to redirect Gen. Musharraf's plane and to dismiss him from the post of army chief. Now Mian Muhammad Nawaz Sharif, who was the master mind, could not succeed in his ambitions and army under the leadership of Gen. Musharraf took over the power. A trial was started in anti-terrorist court Karachi against Mian Nawaz Sharif in so-called plane hijacking case. Anti-terrorist court Karachi gave its verdict on 06 April 2000 in which Mian Nawaz Sharif was convicted to life time imprisonment, his property was seized and he was ordered to compensate the passengers of PIA flight having put their life in grave danger.

It was nothing new that political leaders paved way for their own destruction. The editorial of Dawn on 7 April, 2000 stated this fact that in our history this is the third example of same case. "Mr. Z A Bhutto was sentenced to death by Gen. Zia-ul-Haq, later on Ms. Benazir Bhutto was convicted by the High Court Ehtesab Bureau during Mr. Nawaz's tenure now she lives abroad in a self-imposed exile and Mr. Nawaz himself is in prison. Now Mr. Nawaz and Ms. Bhutto should ask from themselves that who have contributed in their down fall" (The Verdict, 2000). In December Mian Nawaz Sharif was freed from imprisonment on hijacking the plane and corruption charges, exiled to Saudi Arabia and was prohibited from returning to Pakistan for 10 years.

Perhaps Gen. Musharraf was also the victim of same threat from Nawaz Sharif that is why he was exiled to Saudi Arabia and was banned from returning to Pakistan for 10 years. As Ayaz Amir stated this fact referring to Gen. Musharraf's speech of Dec 21, 2000, that at one point he said that he is not afraid of anyone except of God and decision to let Mr. Nawaz go was not due to any fear. At the same time he condemned Mr. Nawaz and Benazir Bhutto for trying to come together in ARD to loot the country once again. If nothing else does not this textual proof betray the doubt that the General might have been protesting too much? (Amir, 
2001) The same cycle was repeating itself in that Mr. Nawaz forced Ms Bhutto for self-imposed exile and Mr. Nawaz was exiled for his life to Saudi Arabia. Now for the time being, the political scene was clear for the General to play the game of politics as he wished.

\section{Dawn and the LFO 2002}

The Supreme Court's judgment of May 12, 2000, allowed the Chief Executive to amend the constitution. Now the announcement of March 05, 2001, made by Gen. Musharraf to hold elections till Oct 2002, made it necessary for the General to amend the constitution to keep his rule secure. Although Gen. Musharraf was an "elected president" now after the referendum of April 2002, yet pre-poll political manipulations could not even make Musharraf feel secure enough. So, Legal Framework Order (LFO) was given in August 2002 which amended almost 29 articles of the constitution including the restoration of clause 58-2(b). This clause was introduced by General Zia and was removed through thirteenth amendment by Mian Nawaz Sharif. Clause 58-2(b) empowers the president to dismiss an elected government in situation when, only in the opinion of President, government could not be carried according to the constitution. A new clause 152A was introduced according to which National Security Council (NSC) was created. The other important changes were: increase in the number of National Assembly seats from 270 to 342,60 seats reserved for women and 10 for minorities and reducing the voting age from 21 to 18 .

On August 20, 2002 LFO announced by Chief Executive opened a new debate in media. The most controversial changes brought through LFO in the constitution were restoration of 58-2(b) and the formation of NSC. The editorial of August 23, in Dawn commented on the restoration of clause 58-2(b) that in contrast with Gen. Musharraf's earlier claims of introducing "checks and balances" between the president and the prime minister, the president has become all too powerful. The prime minister will now be dependent on presidential goodwill, because of the sword of 58-2(b) hanging over his head all the time which is against the norms of parliamentary democracy (Another leap in the dark, 2002). This clause was introduced by Gen. Zia to keep Muhammad Khan Junejo and the elected parliament under his pressure and to ensure his rule as president over them. In his last days Gen. Zia was annoyed with Muhammad Khan Junejo, the PM, and dismissed him by using this clause but very soon after the dismissal he died in an air crash. President Musharraf also wanted to follow the example.

The next most debatable issue was the formation of National Security Council (NSC). NSC was the personal cabinet of president Musharraf the members of which would be nominated by the president himself. As Shameem Akhtar commented on the National Security Council as patterned in LFO will be a supra cabinet which will not be answerable to the parliament. At best LFO is the prescription of the "controlled democracy"; at worst a recipe for dictatorship (Akhtar, 2002). Restoration of eighth amendment was a threat to the government and NSC was a continuous check on its activities. Elected government was going to be a puppet in the hands of NSC which was the handmaid of President General Musharraf.

The editorial of Dawn aptly commented that NSC was an attempt to extract constitutional role for the generals in the country's governance (Another leap in the dark, 2002). Now where was the "essence of democracy", which President Musharraf had promised to give to the country? Till now it has become very clear that the promises and the hopes given to the nation from this fourth military ruler were as meaningless as of the previous military rulers. Shameem Akhtar commented in his column, on the issue of eighth amendment Gen. Zia did better than Gen. Musharraf as he got its validation from elected parliament. On the contrary Gen. Musharraf would not allow the future parliament to approve of or reject the amendments made by him (Akhtar, 2002). In fact this LFO had crossed the limits of all the legalities and had ensured president Musharraf for his future as president. 
President Musharraf was now fully equipped with the powers not only of eighth amendment and NSC, but also of the president, chief executive, chief of army staff and chairman joint chiefs of staff committee. The editorial of the Economist (London), fairly commented on the situation that Mr. Musharraf should remain the dictator as he is, and step down when his job is done, despite indulging in this bogus referendum, LFO or elections. Such exercises give only bad name to democracy. With all these weapons, president Musharraf got desired results from the pseudo elected government of PMLQ (Pakistan Muslim League Quaid i Azam) during the whole period of 2002 to 2008. Neither the parliament nor the PM whether it was Mir Zafar Ullah Khan Jamali, Ch. Shujaat Hussain or Shaukat Aziz, dared any objection to president Musharraf or his amendments in the constitution.

Some opine that such political conflicts are common in the history of Pakistan because our political leaders do not worry for their responsibility and this irresponsible attitude causes the distortion of democratic values and makes the politics uncertain for the common people. But now with the development of media the common people could not remain anymore indifferent to the politics of the country. The situation of this deadlock continued until Gen Musharraf announced the date of December 31, 2004 to shed off his uniform. The seventeenth amendment in the constitution was passed on $1^{\text {st January }} 2007$ through which Musharraf won vote of confidence giving legitimacy to the decisions taken during his rule until 2007. For almost two years after elections a hot contested debate on LFO, section 58-2 (b), NSC and uniform continued but it was the first time in our country's politics that opposition took stand against a very powerful President General Musharraf. Dawn remained highly active and concerned with the whole issue and performed its positive critical role. Not only were the reasons behind the conflict analyzed, but the whole conflict and its solutions were also given full coverage in its editorial page very critically.

\section{Conclusion}

The military intervention of October 12, 1999 introduced a new dimension not only in country's politics but also in media's role in politics. The previous military regimes of Gen. Ayub, Gen. Yahya and Gen. Zia were really very difficult for media because a military dictator never welcomes freedom of expression but the fourth military ruler of Pakistan was forced to do so. Gen. Musharraf took liberal steps regarding media freedom because of international as well as internal pressures. It can safely be opined that in order to compete Indian media and its propaganda strength, Pakistani media was given freedom of expression. The turning point in media's role, amazingly, came during a military regime. But the change in the media's role did not come abruptly but it was the result of gradual process. The time had changed and it was not possible to control the media and show people one sided of the picture. Global demands obligated Musharraf to give the media its due right. The government of PMLN (Pakistan Muslim League Nawaz) had given tough time to media and in October 1999 the fourth martial law was imposed. Gen Musharraf who although never accepted it as martial law and declared it as emergency yet it did not differ from the previous martial laws and suspended the constitution as well as the national and provincial assemblies.

Since the scope of analysis of this paper is only related to the editorial page of the daily Dawn, the editorials and the columns published in the daily Dawn in response of Musharraf's coup of Oct 12, 1999 have been discussed. So far as Dawn is concerned it is the oldest newspaper of Pakistan founded and inaugurated by the father of the nation Muhammad Ali Jinnah himself, in 1941 as a weekly publication as a representative of Muslim League from Delhi. It became a daily newspaper in October, 1942 and very soon got the nationwide fame. After the creation of Pakistan, it was shifted to Karachi and is Pakistan's oldest and most widely read English language newspaper today. Dawn has a repute of being a liberal newspaper. As far as its editorials and columns are concerned, they are not only highly informative but also represent the critical analysis of the issues to develop a positive and constructive public opinion. 
There is no denying the fact that before Musharraf regime, the columnists of Dawn could not write as bluntly as they have written during Musharraf regime. Same is the case with the editorials of the paper because of harsh and rigid rules regarding the press activities and publications. There was a gradual change in the treatment of Dawn about the national issues. Very soon after the promulgation of martial law on October 12, 1999, the print and electronic media welcomed it according to the wishes of the people but Dawn remained very composed and insisted on the restoration of democracy as soon as possible. Some of the columnists like Ayaz Amir wrote very critically about the imposition of martial law and condemned it. Later on, the judgment of the Supreme Court validating the military coup was compared very critically with the judgment given in 1981 validating martial law of Gen Zia. LFO and PCO were treated in the same critical tone by Dawn. The specialty of Dawn is that it not only criticizes the issue but also gives positive and progressive suggestions. In sum, the daily Dawn maintained its high standards and quality whether it was the dark night of military dictatorship or the so-called political democracy. It has never given up the vision of the founder of Pakistani nation, Quaid-i-Azam Muhammad Ali Jinnah, and has performed in accordance with internationally accepted media norms.

\section{References}

Akhtar, S. (2002, August 29). A prescription for controlled democracy, Dawn.

Amir, A. (1999, October 15). What Now? Dawn.

Amir, A. (1999, October 22). Scratchy Record, familiar tune, Dawn.

Amir, A. (1999, December 10). The distinct sound of floundering, Dawn.

Amir, A. (2000, January 28). The weary scene re- enacted, Dawn.

Amir, A. (2000, February 18). Rocket-like Personalities, Dawn.

Amir, A. (2000, March 17). Lost in woods, Dawn.

Amir, A. (2001, December 22). As spoke not Zarathustra, Dawn.

An example to follow elsewhere, (2000, May 24). Dawn.

Another leap in the Dark? (2002, August 23). Dawn.

Askari, M. H. (1999, October 20). What led to the army takeover? Dawn.

At the crossroads yet again, (1999, October 14). Dawn.

Behuria, A. K. (2000, January-June). How Military Dominates the political space in Pakistan: A study of Musharraf's Rule (1999-2008), Journal of peace studies, vol 16, issue 1-2.

Bhatty, M. A. (2000, May 17). Devolution and Democracy, Dawn. 
Cowasjee, A. (1999, October 17). The Coup that failed, Dawn.

Fair Objectives: Question of Time-frame, (1999, October 19). Dawn.

Hiel, B. (2008, March 16). Pakistani Media Caught in Middle. Tribune Review.

https://onpakistan.wordpress.com/2009/12/21/newspaper-readership-in-pakistan/

Hussain, I. (1999, October 16). Democracy in Doldrums, Dawn.

In Months not Years, (1999, October 17). Dawn.

International Media Support (July 2009). Between Radicalization and Democratization in an unfolding conflict: Media in conflict.

Khan, H. (2000, May 24). The verdict and after, Dawn.

Mezzera, M. \& Sial, S. (2010, October). Media and Governance in Pakistan: A Controversial Yet Essential Relationship, [EN] CRU Occasional Paper, The Hague: Clingendial institute.

Return to Democratic rule is of the essence, (1999, October 16). Dawn.

Sattar, B. (2000, April 13). The Institutional Imbalance, Dawn.

Shahid, M. Amin (1999, October 19). What the priorities are, Dawn.

The Verdict (2000, April 07). Dawn.

What the verdict means (2000, May 14). Dawn.

Zia-ud-din, M. (2010, November 6-7). Media, Democracy and Good Governance, Introductory Remarks by SAFMA-Pakistan President in SAFMA National Conference-4, Islamabad. 